\title{
CONTRACT AND AGENCY LAW AND THE 2008 COMPANIES BILL
}

\section{$1 \quad$ Introduction}

There are several sections of this new Bill (final version B61D-2008, adopted by the National Assembly on 19 November 2008) that deal with these topics. Before examining them the author opines that it would be advisable to review the background and the present legal position.

\section{The ultra vires doctrine}

In the $19^{\text {th }}$ century, legislation in the United Kingdom required the memorandum of a company to state its "objects". The courts interpreted this to mean that a company had no capacity to engage in any activity that was not expressly or impliedly authorised by its objects clause. This unfortunate application of the ultra vires doctrine to companies spread to other Commonwealth countries, including South Africa. One of the leading cases is Ashbury Railway Carriage and Iron Co v Riche (1875 LR 7 HL 653). The company's objects clause conferred capacity on the company to manufacture and sell railway carriages. A contract for the construction of a railway line was beyond the powers stated in the objects clause and therefore void. In the words of Lord Cairns the "memorandum of association is as it were, the area beyond which the action of the action of the company cannot go ... The question is not as to the legality of the contract; the question is as to the competency and power of the company to make the contract" (671-672). His lordship rejected the contention that the contract could nevertheless be ratified by the unanimous consent of the company's members: the "shareholders would thereby ... have been attempting to do the very thing which, by the Act of Parliament, they were prohibited from doing" (672). Earlier in his judgment, Lord Cairns said this:

"The provisions under which that system of limiting liability was inaugurated, were provisions not merely, perhaps I might say not mainly, for the benefit of the shareholders for the time being in the company, but were enactments intended also to provide for the interests of two other very important bodies; in the first place, those who might become shareholders ... and, secondly, the outside public, and more particularly those who might be creditors ..." (667).

This was the rationale underlying the doctrine. At the time it seemed eminently logical and reasonable. Time and experience - and some bitter experience at that - were to prove the theory quite unworkable.

The result of the case, and others like it, was that the company missed out on a potentially valuable contract. The reaction of the business community to this and other similar decisions was to "vote with its feet". Since there was no limit to the number of objects a company could have, objects clauses became longer and longer to contain every conceivable activity the company might 
wish to engage in. So evolved what became known as the "multifarious objects clause". This was a farcical document. Objects and powers, for instance, were hopelessly confused. Nobody could tell by reading a company's memorandum what its real business was. But it served its main purpose of avoiding any argument concerning ultra vires and thus preventing the predicament the Ashbury company (supra) found itself in.

\section{The doctrine of constructive notice}

This doctrine complemented - or rather, buttressed - the ultra vires doctrine. Since the memorandum and articles were registered public documents, and thus available for inspection by the public, anyone dealing with a company was deemed to have knowledge of the public documents of a company. At a time when the company population was miniscule, this notion might possibly have made some sense. But when the population expanded into the thousands and hundreds of thousands it not only ceased to make any sense but became a dangerous and entirely unjustifiable trap for persons dealing with companies. They assumed that there could be nothing beyond the scope of a multifarious objects clause. A graphic illustration is provided by Introductions Ltd v National Provincial Bank Ltd (1970 1 Ch 199 (CA)). The company had been formed originally for the purpose of providing accommodation and services for overseas visitors. Following a take-over some years after incorporation, the company changed its business to (of all things!) pig-breeding. Despite the usual multitude of objects, this was the one activity the drafter of the memorandum had not thought of. Who could blame her? The bank, which knew that pig-breeding was the company's sole business, lent it a sum of money to be used in furthering that business, and the company issued certain debentures as security for the loan. It was held that the loan and debentures were ultra vires and therefore void.

\section{$4 \quad$ Reform}

So far as the author is aware, the pernicious ultra vires and constructive notice doctrines have been abolished, or effectively abolished, by legislation in all other jurisdictions where they had taken root. But, be that as it may, the position in South Africa is not entirely clear or satisfactory. What was required was very simple, drastic legislative surgery. But that did not happen.

By 1963, when the Van Wyk de Vries Commission of Enquiry into the Companies Act was appointed, the numerous iniquities and anomalies occasioned by these doctrines made it evident that reform was needed. The topic was dealt with in chapter VII of the Main Report (RP 45/1970). The main recommendation was enacted as section 36 of the Companies Act 61 of 1973. This section was ineptly and clumsily drafted and has now been replicated as section 20(1) of the new Bill. The author will discuss the provisions later in this paper. It was never clear whether the section on its own succeeded in eliminating ultra vires. But it had to be read with two other new sections, namely 33 and 34 , which define the capacity and powers of companies (thereby putting an end to the multifarious objects clause). These two sections are so hazily and vaguely worded that it would be very difficult 
for anyone to prove that any act of a company lay outside its capacity. The result is that, considered jointly, the three sections have effectively muddled through to eliminate the ultra vires doctrine in South Africa as well as the constructive-notice doctrine in so far as it applies to the memorandum. However, as Naude pointed out in a masterly analysis of the whole subject, that constructive notice "still applies with all its vigour to the articles and hence the whole arrangement of directors' powers contained in them" ("Company Contracts: The Effect of Section 36 of the New Act" 1974 SALJ 315 333). However, there have been no reported cases on this since 1973. Nevertheless, South Africa is, so far as the author is aware, the only jurisdiction where, theoretically at least, constructive notice remains partly in force. These issues will be discussed further presently.

\section{The so-called rule in Turquand's case}

In the famous case of the Royal British Bank $v$ Turquand (1856 6 E\&B 327), (119 ER 886), the company's constitution permitted the directors to borrow on bond such sums as might be authorized by resolution of the company in general meeting. A certain loan agreement was held to have been validly concluded despite the fact that the required resolution had not been passed:

"We may now take for granted that dealings with these companies are not like dealings with other partnerships, and that parties dealing with them are bound to read the [memorandum and articles]. But they are not bound to do more. And the party here, on reading [them], would find not a prohibition from borrowing, but a permission to do so on certain conditions. Finding that the authority may be made complete by a resolution he would have a right to infer the fact of a resolution authorizing that which on the face of the document appeared to be legitimately done" (332 per Jervis CJ).

The Turquand or "indoor management" rule, as it is sometimes referred to, is usually expressed by saying that a person dealing with a company in good faith is entitled to assume that all internal formalities and acts of management have been duly performed and carried out. It is clear from the judgment that the rule was designed to temper the effects of constructive notice (see, eg, Pretorius Hahlo's South African Company Law Through the Cases 6ed (1999) 360-361). What it means, in essence, is that constructive notice cannot go beyond what is actually stated in the relevant document. If outsiders were expected to investigate the internal workings of a company, they would be in an impossible situation and nobody could safely contract with companies.

However, as the cases have shown, the matter is nowhere nearly as simple as it sounds. The way the author has expressed the rule in the previous paragraph is the usual one you will find in most text-books. Unfortunately, phrased in the positive as it is, the rule is inaccurate and misleading because it carries the implication that a third party dealing with a person professing to be a company's agent can simply assume the agent's authority. The author suspects that this is the basis of the theory advanced by Blackman, Jooste and Everingham who contend that the rule is some kind of sui generis "independent rule of company law": Commentary on the Companies Act Vol I (2002) 4 -44-49. Nowhere, as will be seen below, does the case-law support such propositions. 
There is a world of difference between saying, positively, that "I am entitled to assume that something has been done" and saying, negatively, that "you cannot escape liability solely on the ground that something has not been done". It may be that the confusion that has arisen is ascribable to what the philosophers call the "undistributed middle". You may authorise me to enter into, on your behalf, contracts with third parties. Professing to act as your agent, I purport to conclude, on your behalf, a certain contract with X. In fact, you never gave me any such authorisation nor did you do anything to represent to $X$ that I possessed any such authority. Can $X$ be heard to say that "you could have authorised him and I am entitled to assume that you did so"? The notion is patently absurd. Suppose, to change the facts slightly, you are a company. In terms of your articles, your board of directors has the power, by means of an internal resolution, to appoint any agent to enter into a certain contract on your behalf. The other facts remain the same. No resolution was passed and your company did nothing to represent to $X$ that $I$ was your agent. Can X be heard to say that "you could have authorised him, by means of an internal act of management, and I am therefore entitled to assume that the requisite resolution was duly passed"? The notion is equally absurd (see Wolpert v Uitzicht Properties (Pty) Ltd (1961 2 SA 257 (W) 263). What the author will attempt to show is that the so-called Turquand rule has no positive operation at all. Only when $X$ has established the basic requirements of ostensible authority, may the non-compliance with internal formalities have any relevance.

The indoor management rule is no substitute for any of the basic principles of the common law of agency. This was clearly demonstrated as long ago as 1927 in two decisions of the Court of Appeal. In Houghton \& Co v Nothard, Lowe and Wills Ltd (1927 1 KB 246 (CA)) the company's articles authorised the board to delegate authority to any of its members. An ordinary director purported to enter into a contract on the company's behalf with a third party. The director had not been delegated any authority to conclude the contract, but the third party contended that, as a matter of internal management, he was entitled to believe that the delegation had been duly carried out. The court of Appeal rejected this. To apply the Turquand rule in these circumstances would, in the opinion of Sargant LJ,

\begin{abstract}
"carry the doctrine of presumed power far beyond anything that has hitherto been decided, and to place limited companies, without any sufficient reason for so doing, at the mercy of any servant or agent who should purport to contract on their behalf. On this view, not only a director of a ... company ... but a secretary or any subordinate officer might be treated by a third party acting in good faith as capable of binding the company by any sort of contract, however exceptional, on the ground that a power of making such a contract might conceivably have been entrusted to him ... I know of no case in which an ordinary director, acting without authority in fact, has been held capable of binding a company by a contract with a third party, merely on the ground that that third party assumed that the director had been given authority by the board to make the contract" (266-267).
\end{abstract}

The matter was put even more forcefully by Atkin LJ in Kreditbank Cassel GmbH v Schenkers Ltd (1927 1 KB 826 (CA) 842-843):

"One reason for seeking to impose liability upon [the company] is this, it is said:

'You, the defendants, are a limited company, and as such you are in a much 
more awkward position than if you were a firm, because you have an article in your articles of association empowering the directors to determine who may sign bills of exchange on behalf of the company, and, therefore, anyone who purports to sign a bill of exchange in the name of the company is deemed to have authority to do so.' Carried to its logical conclusion, that would be a most alarming doctrine for companies, for any one who has the pen of a ready writer need only sit down and write a bill of exchange in the name of a company having an article in this form, and the company would, presumably, be bound ... even although the bill was an absolute forgery. The article cannot have that extended bearing, and if some limitation were not placed upon it, not merely the office boy but anyone might purport to sign on behalf of the company. Such a view is not correct."

As long ago as 1927, two essential points about Turquand had been clearly established: first, that the rule in no way derogated from the basic principles of the common law of agency, and second, the rule could have no positive application. It was purely a negative rule whose sole function was to mitigate the operation of another negative rule, namely, constructive notice. Much more recently, in Nieuwoudt NNO v Vrystaat Mielies (Edms) Bpk (2004 3 SA 486 (SCA)), it was argued that the Turquand rule applied to business trusts. Harms JA saw the point quite clearly:

"What needs to be emphasised is that even if the Turquand rule is extended to business trusts, and even if a trust deed were to provide that the trustees could delegate their powers to one of their number, the Turquand rule could without more be of no assistance to third parties. This is because a third party would not be entitled to assume, merely from the fact that one trustee can be authorised to exercise the powers of all of them, that such authorisation had been given ..." (494GH).

Precisely: what "more" is required is, obviously, one of the fundamentals either an actual delegation of authority or facts establishing an estoppel.

In any event, the myth that the Turquand rule was some kind of magic formula operating above and beyond the common law of agency was definitively disposed of in 1927 in the two cases discussed above.

\section{$6 \quad$ Estoppel}

A case that clearly showed the limitations of the rule is Service Motor Supplies (1956) (Pty) Ltd v Hyper Investments (Pty) Ltd (1961 4 SA 842 (A)). Article 103 of the appellant's articles of association provided that "no resolution of the directors shall be valid or binding upon the company unless such resolution [is] passed unanimously by all the directors of the company". A resolution to enter into a lease of immovable property was "passed" in the absence and without the knowledge of one of the directors. Here, evidently, was an archetypal Turquand situation: all the court had to say was that the third party could assume that the resolution had been validly passed as a matter of internal formality. But the court knew that the law of agency does not operate in this way and therefore did not take this approach. Hoexter ACJ held that, having regard to all the circumstances surrounding the conclusion of the contract, the company was estopped from denying that it was bound by act of its agent who had signed the lease. Although the Turquand rule had been referred to and argued before the court, it received not a single mention in the judgment; it was irrelevant. Had the facts not established ostensible authority, 
the contract would have been invalid. This illustrates the very small scope and operation of the rule: if the third party can prove ostensible authority, internal irregularities can be ignored.

Writing a few years before this case, Thompson put the matter thus:

"It might be said that the indoor management rule does not exist as a positive rule of law at all. It is merely an acknowledgement that, in reference to apparent authority, constructive notice is not to be carried beyond the memorandum and articles to include matters of mere procedure, such as quorums, voting and internal resolutions and regulations. On this view, the indoor management rule may be classed as simply an expression of the apparent authority doctrine in the field of company law" ("Company Law Doctrines and Authority to Contract" 1955-1956 University of Toronto LJ 248257 ).

In three short sentences, he sums up the entire situation with brilliant lucidity.

The most instructive judgment on this topic generally is, in the author's opinion, written by Diplock LJ in Freeman \& Lockyer $v$ Buckhurst Park Properties (Mangal) Ltd (1964 2 QB 480 (CA), 19641 All ER 630). The board of directors of the $\mathrm{B}$ Co consisted of $\mathrm{K}, \mathrm{H}$ and two nominees. The articles permitted the board to appoint a managing director, but no actual appointment was ever made. However, $\mathrm{K}$, although not formally appointed, acted as managing director: he assumed responsibility for the management and control of the company's affairs with the full knowledge and acquiescence of his codirectors. He instructed the plaintiffs to do certain work for the company - the type of contract that normally would fall within the scope of a managing director's authority. When sued for the plaintiff's fees, the company denied that $\mathrm{K}$ had authority to bind it. The company was held liable.

Although Diplock LJ considered that $\mathrm{K}$ had actual (implied) authority to act, his lordship proceeded to decide the case on the basis of apparent authority. $\mathrm{He}$ formulated a test that must be complied with by a third-party contractor seeking to hold a company liable on the ground of estoppel. He must prove four things:

"(1) that a representation that the agent had authority to enter on behalf of the company into a contract of the kind sought to be enforced was made to the contractor;

(2) that such representation was made by a person or persons who had 'actual' authority to manage the business of the company either generally or in respect of those matters to which the contract relates;

(3) that he (the contractor) was induced by such representation to enter into the contract, that is, that he in fact [reasonably] relied upon it;

(4) that under its memorandum or articles of association the company was not deprived of the capacity either to enter into a contract of the kind sought to be enforced or to delegate authority to enter into a contract of that kind to the agent" $(506,646)$.

It should be noted that conditions (1), (2) and (3) are entirely consonant with the common law of agency both in England and in South Africa. Condition (4) puts the Turquand rule into proper perspective: it is not a positive rule of law; it has a purely negative function and comes into operation - if need be - only when the essential requirements of estoppel have been established. The rule is best expressed, in the author's submission, in these 
terms: an estoppel set up against a company is not defeasible merely because some internal formality has not been complied with. This is the very narrow ambit within which the so-called rule operates. In the Service Motor case (supra) the Appellate Division did not even bother to mention it.

At the time when the Freeman judgment was written, the ultra vires and constructive-notice doctrines were in full operation in England. Abolish these and condition (4) disappears in its entirety. And, naturally, without constructive notice, the Turquand rule has no function; it is no longer needed. Future cases of this nature would be decided purely on common-law principles (conditions (1), (2) and (3)).

Proving the actual or ostensible authority of an alleged agent can often be difficult. The artificial doctrines of ultra vires and constructive notice never did anything to facilitate the enquiry. On the contrary, they only bedevil and complicate the issues and cause injustices.

It is against this background that the provisions of the new Bill must be analysed and evaluated.

\section{The 2008 Companies Bill}

\section{Ultra vires and constructive notice}

There are a number of rather puzzling provisions involved. The author opines that it would be best to discuss them in their order of appearance. First, section 13(3):

"If a company's memorandum of incorporation includes any provision contemplated in section 15 (2) (b) or (c), the Notice of Incorporation filed by the company must include a prominent statement drawing attention to each such provision, and its location in the memorandum of incorporation."

This is a very novel concept. What is prominence and what use is it to someone who has not read the memorandum?

In terms of section 15 (2), the memorandum may -

"(b) contain any special conditions applicable to the company, and any requirement for the amendment of any such condition in addition to the requirements set out in section 16; or

(c) prohibit the amendment of any particular provision of the memorandum of incorporation."

The link between special conditions and the capacity of companies is set out in section 19. In terms of subsection (1) (b), a company

"has all of the legal powers and capacity of an individual, except to the extent that -

(i) a juristic person is incapable of exercising any such power, or having any such capacity; or

(ii) the company's memorandum of incorporation provides otherwise." 
"(4) Subject to subsection (5), a person must not be regarded as having received notice or knowledge of the contents of any document relating to a company merely because the document

(a) has been filed; or

(b) is accessible for inspection at an office of the company."

"(5) A person must be regarded as having received notice and knowledge of -

(a) any provision of a company's memorandum of incorporation contemplated in section 15(2)(b) if the company's Notice of Incorporation or a Notice of Amendment has drawn attention to the provision, as contemplated in section 13(3)".

There is no definition of "special condition" in the Bill. One wonders what the framers of the Bill had in mind. Why do they not tell us? We must perforce resort to speculation, inference and, perhaps, even guesswork. Section 19(1)(b)(ii) would seem to suggest that it is a provision that somehow limits or restricts the capacity of a company. So may a company again have a restricted objects clause as existed in the olden days? Could there be provisions such as effectively prohibiting building railroads (cf the Ashbury case supra)? Subsection 5(a) would seem to extend the doctrine of constructive notice to special conditions. That might mean that incorporators could set up a regime that resurrects ultra vires in all its pristine frightfulness.

Subsections (1)(b)(i) and (4)(a) and (b) use much the same wording as sections 2(4) and 17 of the Close Corporations Act 69 of 1984. If those sections of the Bill had not been qualified they would have succeeded in ridding company law of ultra vires and constructive notice once and for all.

What the author suspects the drafters of the Bill were trying to achieve again the author is speculating - is some sort of limited ultra vires regime that applies to insiders but not to outsiders. If the author is anywhere near correct, he has to say the idea makes little sense to him. Either the company has capacity to do something or it does not. How can some activity be intra vires vis-a-vis outsiders but ultra vires vis-a-vis insiders?

If companies are minded to limit the powers of directors, this can easily be achieved by employing the law of contract. In their contracts of appointment, the directors undertake not to engage the company in this, that or the other specified activity; or only to engage the company in certain specified activities. Should directors renege on their obligations and the company suffers loss, they will be liable for damages for breach of contract. But, of course, this would not affect the rights of bona fide outsiders contracting with the company. The author cannot imagine that many such contractual provisions could or would exist, but if a company is determined to restrict its activities by tying its own hands, this would be the way to do it.

The story does not end here. We must now go to section 20, parts of which seem to go a long way toward negating subsections 19(1)(b)(ii) and (5). Subsection (1) runs thus:

"If a company's memorandum of incorporation limits, restricts or qualifies the purposes, powers, or activities of that company, as contemplated in section 19(1)(b)(ii) -

(a) no action of the company is void by reason only that - 
(i) the action was prohibited by that limitation, restriction or qualification; or

(ii) as a consequence of that limitation, restriction or qualification, the directors had no authority to authorise the action by the company; and

(b) in any legal proceeding, other than proceedings between -

(i) the company and its shareholders, directors or prescribed officers; or

(ii) the shareholders and directors or prescribed officers of the company,

no person may rely on such limitation, restriction or qualification to assert that an action contemplated in paragraph (a) is void."

This subsection closely follows the wording of the existing section 36 . So far as outsiders dealing with a company are concerned, it would appear that the provisions the author has quoted above from sections 13,15 and 19 have no application - except section 19(4). The doctrines of ultra vires and constructive notice would be effectively eliminated so far as outsiders are concerned. The concluding words of paragraph (b) peremptorily exclude any assertion of lack of capacity. However, these doctrines may be raised in litigation between insiders. Subsections (1)(b)(i) and (ii) evidently exclude certain insiders from the protection of the section. The author has no difficulty as regards directors and other officers who are under a fiduciary duty to ensure that the affairs of the company are properly conducted in accordance with its constitution. They cannot be heard to say that they were unaware of the provisions of the constitution: see Hahlo's South African Company Law through the Cases (supra 361) and the authorities there discussed. (It follows that a contractor in such a position cannot be said to rely reasonably on any representation contemplated in condition (3) of the test in the Freeman case (supra)).

But shareholders qua shareholders are in a different position. Unlike directors, they have no access to the company's private and internal workings and records and thus have no way of ascertaining whether, for instance, a certain resolution was validly passed. They are not fiduciaries. If they are saddled with the burden of constructive notice they might suffer unfair prejudice. A person, in all good faith, enters into a contract with a company only to discover later that he or she cannot enforce the contract merely because he or she happens to hold a tiny fraction of the company's equity. This is not a good idea.

\section{The Turquand rule}

Section 20 (7) provides the following:

"A person dealing with a company in good faith, other than a director, prescribed officer or shareholder of the company, is entitled to presume that the company, in making any decision in the exercise of its powers, has complied with all of the formal and procedural requirements in terms of this Act, its memorandum of incorporation and any rules of the company unless, in the circumstances, the person knew or reasonably ought to have known of any failure by the company to comply with any such requirement."

This subsection is evidently a rendering of the Turquand rule. The author hopes he has persuaded the reader that it is an inaccurate rendering. But there is no need to labour this point. Insiders, including shareholders, are 
expressly excluded from its "protection". So we must conclude that it is intended to protect outsiders. But, as we have seen, outsiders are fully protected by subsection (1) (and 19(4)). This subsection (7) therefore serves no purpose at all. It can only cause confusion. It could give rise to the sort of difficulty the author discusses in the paragraph immediately preceding this one.

\title{
73 The way forward
}

When the Close Corporations Act 69 of 1984 was drawn up, the legislators were determined that these corporations would not be bedevilled by the artificial doctrines of ultra vires and constructive notice. These were very competently eliminated in two short sections:

\begin{abstract}
"2(4) A corporation shall have the capacity and powers of a natural person of full capacity in so far as a juristic person is capable of having such capacity or of exercising such powers ...

17 No person shall be deemed to have knowledge of any particulars merely because such particulars are stated, or referred to, in any founding statement or other document regarding a corporation registered by the Registrar or lodged with him, or which is kept at the registered office of a corporation in accordance with the provisions of this Act."
\end{abstract}

The author has never understood why similar provisions were not put into the Companies Act. Nothing more is needed than to make the necessary changes to the nomenclature. The wording of subsections 19(1)(b)(i) and (4) of the new Bill closely follows that of the two provisions quoted above, but, unfortunately, they are qualified. The author's submission is that all the provisions of the Bill that he has quoted in this paper ought to be taken out with the sole exceptions of subsections 19(1)(b)(i) and (4) - but without any qualification; in other words, use the same model as in the Close Corporations Act. The effect of this would be that, in future, questions relating to the actual and ostensible authority of company agents would be resolved by the rules of our common law of agency - entirely untrammelled with misconceived and pernicious doctrines that should never have been imported into our law. And Mr Turquand would finally rest in peace in his grave!

JS McLennan University of KwaZulu-Natal 